\title{
Clinical characteristics and outcome of influenza virus infection among adults hospitalized with severe COVID-19: A retrospective cohort study from Wuhan, China
}

\author{
Xunliang Tong \\ Beijing Hospital \\ Xiaomao Xu \\ Beijing Hospital \\ Guoyue Lv \\ The First Hospital, Jilin University \\ He Wang \\ Beijing Hospital \\ Anqi Cheng \\ China-Japan Friendship Hospital \\ Dingyi Wang \\ China-Japan Friendship Hospital \\ Guohui Fan \\ China-Japan Friendship Hospital \\ Yue Zhang \\ Beijing Hospital \\ Yanming Li ( $\square$ lymyl@263.net) \\ Beijing Hospital
}

\section{Research article}

Keywords: COVID-19, influenza virus, SARS-CoV-2

Posted Date: January 15th, 2021

DOI: https://doi.org/10.21203/rs.3.rs-50577/v2

License: (9) (1) This work is licensed under a Creative Commons Attribution 4.0 International License. Read Full License 


\section{Abstract}

\section{Background}

Coronavirus disease 2019 (COVID-19) is an emerging infectious disease that rapidly spreads worldwide and co-infection of COVID-19 and influenza may occur in some cases. We aimed to describe clinical features and outcomes of severe COVID-19 patients with co-infection of influenza virus.

Methods

Retrospective cohort study was performed and a total of 140 patients with severe COVID-19 were enrolled in designated wards of SinoFrench New City Branch of Tongji Hospital between Feb 8th and March 15th in Wuhan city, Hubei province, China. The demographic, clinical features, laboratory indices, treatment and outcomes of these patients were collected.

Results

Of 140 severe COVID-19 hospitalized patients, including 73 patients (52.14\%) with median age 62 years were influenza virus IgM-positive and 67 patients (47.86\%) with median age 66 years were influenza virus IgM-negative. 76 (54.4\%) of severe COVID-19 patients were males. Chronic comorbidities consisting mainly of hypertension (45.3\%), diabetes (15.8\%), chronic respiratory disease (7.2\%), cardiovascular disease (5.8\%), malignancy (4.3\%) and chronic kidney disease (2.2\%). Clinical features, including fever $\left(\geq 38^{\circ} \mathrm{C}\right)$, chill, cough, chest pain, dyspnea, diarrhea and fatigue or myalgia were collected. Fatigue or myalgia was less found in COVID-19 patients with IgM-positive (33.3\% vs $50 / 7 \%, P=0.0375$ ). Higher proportion of prolonged activated partial thromboplastin time (APTT) $>42$ s was observed in COVID-19 patients with influenza virus IgM-negative (43.8\% vs $23.6 \%, P=0.0127)$. Severe COVID-19 Patients with influenza virus IgM positive have a higher cumulative survivor rate than that of patients with influenza virus IgM negative (Log-rank $P=0.0308$ ). Considering age is a potential confounding variable, difference in age was adjusted between different influenza virus IgM status groups, the $\mathrm{HR}$ was $0.29(95 \% \mathrm{Cl}, 0.081$ 1.100). Similarly, difference in gender was adjusted as above, the HR was $0.262(95 \% \mathrm{Cl}, 0.072-0.952)$ in the COX regression model.

Conclusions

Influenza virus IgM positive may be associated with decreasing in-hospital death.

\section{Background}

In December 2019, a novel coronavirus with high similarity to the coronavirus responsible for severe acute respiratory syndrome (SARS-CoV) appeared and was later named as SARS-CoV-2[1-3]. In 2020, the World Health Organization (WHO) announced that the pandemic of Coronavirus disease 2019 (COVID-19) has constituted a public health emergency of international concern[4].

Previous studies have focused primarily on COVID-19 patients' clinical features with fever accompanied with respiratory and/or gastrointestinal symptoms, and so on[5, 6], which were highly similar to the clinical manifestation of influenza like illness (ILI). ILI may occur in population as co-infection of SARS-CoV-2 and influenza virus during the pandemic. Sustained surveillance of ILI has been implemented by Centers for Disease Control and Prevention (CDC) [7-9] and the co-infection of influenza viruses and SARS-CoV-2 was possible at 20192020 influenza season[2,10]. According to previous study, influenza virus-specific antibody responses following influenza infection rises in HA-specific serum IgM (86 to 94\%) antibodies after primary influenza virus infection in adults[11]. Therefore, HA-specific serum IgM can be identified as the marker of influenza virus infection in COVID-19 patients. The aims of this study were to describe the clinical features and outcomes of hospitalized COVID-19 patients, who were also positive of influenza virus IgM.

\section{Methods}

\section{Study design}

This was a retrospective cohort study which was performed during Feb 8th to March 15th at wards designated for patients with COVID-19 in the Sino-French New City Branch of Tongji Hospital in Wuhan city, Hubei province, China. Total of 140 patients diagnosed of COVID-19 pneumonia was enrolled from two wards managed by multidisciplinary team from Beijing Hospital and First Hospital attached to Jilin University (Figure 1). The study was approved by Ethics Committee of Beijing Hospital (2020BJYYEC-046-01).

The inclusion criteria: throat-swab specimen from upper respiratory tract that were obtained and tested by RT-PCR for confirmation of SARSCoV-2 as the same protocol described previously[1, 12]; pneumonia confirmed by thoracic CT scan[13], an oxygen saturation (SaO2) of 94\% or less while they were breathing ambient air or a ratio of the partial pressure of oxygen ( $\mathrm{PaO} 2$ ) to the fraction of inspired oxygen ( $\mathrm{FiO2}$ ) at or 
below $300 \mathrm{mmHg}[14]$. Exclusion criteria included without examined influenza virus IgM in the first 24 hours in hospital, sudden death within 24 hours.

\section{Data collection}

All the data from electronic medical records were reviewed by experienced physicians separately and checked by 2 physicians independently. The baseline of clinical data was recorded in the first 24 hours after administration and all interventions and the highest level of oxygen support during hospitalization were recorded.

Throat swab samples were collected for SARS-CoV-2 detection from patients by local Centers for Disease Control and Prevention, local health institutions. The PCR re-examination was conducted by throat-swab specimens after clinical remission of symptoms, including fever, cough, and dyspnea. A patient was allowed to discharge if he was clinical improvement and two throat-swab samples negative for SARSCoV-2 RNA obtained at least $24 \mathrm{~h}$ apart [14]. Peripheral blood samples from patients were taken for identification of influenza virus-specific antibody lgM which responses following influenza infection and detected by indirect immunofluorescence assay (Respiratory tract 8 joint detection kit; EUROIMMUN, Inc., Germany) [11, 15, 16].

\section{Statistical analysis}

Descriptive analyses of the variables were expressed as median (interquartile range [IQR]) or number (\%) and compared using Mann-Whitney test. Categorical data were compared using $X^{2}$ test or the Fisher exact test, where appropriate. The patients' characteristics of deaths verses discharged and death/discharge \& influenza IgM positive/negative were also described and shown in Supplementary Table 1 and 2. KaplanMeier curve was portrayed by influenza virus IgM positive/negative to describe the cumulative survival rate of COVID-19 patients. COX regression model was fitted to investigate the association between influenza virus IgM positive and the in-hospital death. To avoid overfitting, at most two covariates were allowed to the model and we adjusted for age and gender respectively in the model. Adjusted hazard ratios (aHRs) and 95\% confidence intervals (95\% Cls) were then estimated. All tests were 2-sides, and a P value less than .05 was considered statistically significant. All analyses were performed with SPSS, version 23.0 (IBM inc.).

\section{Results}

\section{Baseline characteristics}

A total of 140 adult patients confirmed with COVID-19 from designated hospital was enrolled in this study, with 73 patients (52.14\%) were identified as influenza virus IgM-positive. 76 (54.4\%) of the COVID-19 patients were males. The median age of patients with influenza virusIgM negative was 66 years (IQR, 55 to 70 years), older than patients with influenza virus IgM-positive (median age 62, IQR, 47 to 70 years, $P=$ 0.1118). Chronic comorbidities consisting mainly of hypertension (45.3\%), diabetes (15.8\%), chronic respiratory disease (7.2\%), cardiovascular disease (5.8\%), malignancy (4.3\%) and chronic kidney disease $(2.2 \%)$. Clinical features, including fever $\left(\geq 38^{\circ} \mathrm{C}\right)$, chill, cough, chest pain, dyspnea, diarrhea and fatigue or myalgia were collected. Fatigue or myalgia was less found in COVID-19 patients with IgMpositive (33.3\% vs 50/7\%, $P=0.0375)$. (Table 1 )

\section{Table 1. Clinical Characteristics of COVID-19 Patients with and Without Influenza IgM positive.}




\begin{tabular}{|c|c|c|c|c|}
\hline Study Population & $\begin{array}{l}\text { With Influenza IgM positive } \\
(\mathrm{n}=73)\end{array}$ & $\begin{array}{l}\text { Without Influenza IgM positive } \\
\qquad(\mathrm{n}=67)\end{array}$ & $\begin{array}{c}\text { Total } \\
(\mathrm{n}=140)\end{array}$ & $P$ value \\
\hline \multicolumn{5}{|l|}{ Demographic } \\
\hline Gender, Male & $39(53.4)$ & $37(55.2)$ & $76(54.3)$ & 0.8310 \\
\hline Age, media (IQR), yrs & $62.0(47.0,70.0)$ & $66.0(55.0,70.0)$ & $65.0(48.5,70.0)$ & 0.1118 \\
\hline \multicolumn{5}{|l|}{ Comorbidities } \\
\hline Hypertension & $32 / 70(45.7)$ & $30 / 67(44.8)$ & $62 / 137(45.3)$ & 0.9122 \\
\hline Diabetes & $12 / 72(16.7)$ & $10 / 67(14.9)$ & $22 / 139(15.8)$ & 0.7787 \\
\hline Chronic respiratory disease & $5 / 72(6.9)$ & $5 / 67(7.5)$ & $10 / 139(7.2)$ & 0.9060 \\
\hline Cardiovascular disease & $5 / 72(6.9)$ & $3 / 67(4.5)$ & $8 / 139(5.8)$ & 0.5301 \\
\hline Malignancy & $3 / 72(4.2)$ & $3 / 67(4.5)$ & $6 / 139(4.3)$ & 0.9282 \\
\hline Chronic kidney disease & $2 / 72(2.8)$ & $1 / 67(1.5)$ & $3 / 139(2.2)$ & 0.5983 \\
\hline \multicolumn{5}{|l|}{ Signs and symptoms } \\
\hline Fever & $55(75.3)$ & $53(79.1)$ & $108(77.1)$ & 0.5964 \\
\hline Highest temperature, ${ }^{\circ} \mathrm{C}$ & $38.5(38.0,39.0)$ & $38.7(38.2,39.0)$ & $38.5(38.0,39.0)$ & 0.1274 \\
\hline Chills & $13(17.8)$ & $19(28.4)$ & $32(22.9)$ & 0.1375 \\
\hline Cough & $41 / 72(56.9)$ & $44 / 67$ (65.7) & $85 / 139(61.2)$ & 0.2915 \\
\hline Productive cough & $20 / 72(27.8)$ & $25 / 67(37.3)$ & $45 / 139(32.4)$ & 0.2299 \\
\hline Chest pain/Chest congestion & $19 / 72(26.4)$ & $13 / 67(19.4)$ & $32 / 139(23.0)$ & 0.3283 \\
\hline Dyspnea & $21 / 72(29.2)$ & $29 / 67(43.3)$ & $50 / 139(36.0)$ & 0.0831 \\
\hline Diarrhea & $18(24.7)$ & $25(37.3)$ & $43(30.7)$ & 0.1049 \\
\hline Fatigue or myalgia & $24 / 72(33.3)$ & $34 / 67(50.7)$ & $58 / 139(41.7)$ & 0.0375 \\
\hline \multicolumn{5}{|l|}{ Laboratory findings, median (IQR) } \\
\hline White blood cells, $\times 10^{9} / \mathrm{mL}$ & $5.7(4.2,6.8)$ & $5.7(4.6,7.9)$ & $5.7(4.4,7.2)$ & 0.3226 \\
\hline Neutrophils, $\times 10^{9} / \mathrm{mL}$ & $3.9(2.5,4.8)$ & $4.0(2.6,5.9)$ & $3.9(2.5,5.3)$ & 0.3600 \\
\hline Lymphocytes, $\times 10^{9} / \mathrm{mL}$ & $1.2(0.9,1.6)$ & $1.1(0.8,1.5)$ & $1.1(0.8,1.5)$ & 0.3826 \\
\hline Lymphocytes $<0.8 \times 10^{9} / \mathrm{mL}$ & $18 / 73(24.7)$ & $18 / 66(27.3)$ & $36 / 139(25.9)$ & 0.7252 \\
\hline Red blood cells, $\times 10^{12} / \mathrm{mL}$ & $4.1(3.6,4.6)$ & $4.0(3.7,4.4)$ & $4.0(3.7,4.5)$ & 0.4502 \\
\hline Platelets, $\times 10^{9} / \mathrm{mL}$ & $230.0(173.0,292.0)$ & $253.0(169.0,340.0)$ & $235.0(169.0,312.0)$ & 0.3622 \\
\hline Platelets $<100 \times 10^{9} / \mathrm{mL}$ & $5 / 73(6.8)$ & $6 / 66(9.1)$ & $11 / 139(7.9)$ & 0.6249 \\
\hline Hemoglobin, $\mathrm{g} / \mathrm{L}$ & $122.0(114.0,137.0)$ & $125.5(113.0,137.0)$ & $123.0(113.0,137.0)$ & 0.9143 \\
\hline $\mathrm{ALT}, \mathrm{U} / \mathrm{L}$ & $23.0(17.0,40.0)$ & $22.5(15.0,41.0)$ & $23.0(16.0,41.0)$ & 0.7373 \\
\hline AST, U/L & $26.0(19.0,37.0)$ & $30.0(19.0,41.0)$ & $28.0(19.0,39.0)$ & 0.3370 \\
\hline Albumin, $\mathrm{g} / \mathrm{L}$ & $36.1(32.2,38.3)$ & $35.0(31.4,37.1)$ & $35.2(31.7,38.1)$ & 0.2945 \\
\hline Creatinine, $\mu \mathrm{mol} / \mathrm{L}$ & $70.0(60.0,89.5)$ & $70.0(59.0,87.0)$ & $70.0(59.0,89.0)$ & 0.8596 \\
\hline $\mathrm{LDH}, \mathrm{U} / \mathrm{L}$ & $268.5(204.0,329.5)$ & $287.0(235.0,351.0)$ & $281.0(212.0,334.0)$ & 0.2419 \\
\hline $\mathrm{LDH}>245 \mathrm{U} / \mathrm{L}$ & $44 / 72(61.1)$ & $47 / 65(72.3)$ & $91 / 137(66.4)$ & 0.1658 \\
\hline Troponin>15.6pg/mL, No (\%) & 7/51 (13.7) & $12 / 56(21.4)$ & 19/107 (17.8) & 0.2977 \\
\hline NT-proBNP, pg/mL & $140.0(60.0,334.0)$ & $157.0(64.0,459.0)$ & $151.0(63.0,411.0)$ & 0.2883 \\
\hline NT-proBNP $\geq 247 \mathrm{pg} / \mathrm{mL}$, No (\%) & $29 / 57(50.9)$ & $35 / 58(60.3)$ & $64 / 115(55.7)$ & 0.3069 \\
\hline $\mathrm{CRP}, \mathrm{mg} / \mathrm{L}$ & $21.3(4.1,49.2)$ & $34.7(9.1,73.4)$ & $27.2(6.1,69.8)$ & 0.1281 \\
\hline $\mathrm{CRP} \geq 1 \mathrm{mg} / \mathrm{L}$, No $(\%)$ & $57 / 61(93.4)$ & $47 / 49(95.9)$ & $104 / 110(94.5)$ & 0.5651 \\
\hline IL-6, $\mathrm{pg} / \mathrm{mL}$ & $9.8(4.2,21.1)$ & $6.8(3.6,23.2)$ & $9.4(3.9,23.2)$ & 0.5603 \\
\hline IL-6 $\geq 7 \mathrm{pg} / \mathrm{mL}$, No (\%) & $25 / 42(59.5)$ & $15 / 35(42.9)$ & $40 / 77(51.9)$ & 0.1450 \\
\hline Ferritin, $\mu \mathrm{g} / \mathrm{L}$ & $522.1(320.5,729.0)$ & $630.5(310.2,1519.9)$ & $562.6(320.5,986.5)$ & 0.0964 \\
\hline Ferritin $>150 \mu \mathrm{g} / \mathrm{L}$, No (\%) & $39 / 43(90.7)$ & $33 / 35(94.3)$ & $72 / 78(92.3)$ & 0.5495 \\
\hline $\mathrm{PT}, \mathrm{s}$ & $13.7(13.2,14.3)$ & $13.8(13.4,14.2)$ & $13.8(13.3,14.3)$ & 0.9762 \\
\hline APTT, s & $39.6(35.8,42.0)$ & $39.5(37.8,45.8)$ & $39.6(36.6,44.3)$ & 0.0243 \\
\hline APTT>42s, No (\%) & $17 / 72(23.6)$ & $28 / 64(43.8)$ & $45 / 136(33.1)$ & 0.0127 \\
\hline FIB, $g / L$ & $4.9(3.9,6.0)$ & $5.3(4.3,6.2)$ & $5.0(4.1,6.1)$ & 0.2374 \\
\hline D-Dimer, $\mu \mathrm{g} / \mathrm{mL}$ & $0.7(0.5,1.7)$ & $1.2(0.5,2.1)$ & $1.0(0.5,2.0)$ & 0.2371 \\
\hline D-Dimer $\geq 0.5 \mu \mathrm{g} / \mathrm{mL}$, No (\%) & $53 / 73(72.6)$ & $45 / 64(70.3)$ & $98 / 137(71.5)$ & 0.7669 \\
\hline
\end{tabular}

Note. Data are presented as n (\%) or median (IQR, interquartile range) for each parameter. $P$ values were calculated by chi-square test, Fisher's exact test, or Mann-Whitney U test, where appropriate.

Abbreviations. IQR, interquartile range; ALT, alanine aminotransferase; AST, aspartate aminotransferase; LDH, lactic Acid dehydrogenase; CRP, Creactive protein; IL-6, interleukin-6; PT, prothrombintime; APTT, activated partial thromboplastin time; FIB, fibrinogen 
Higher proportion of prolonged activated partial thromboplastin time (APTT) > $42 \mathrm{~s}$ was observed in COVID-19 patients with influenza virus IgM-negative (43.8\% vs $23.6 \%, P=0.0127)$. (Table1) Counts of lymphocytes and platelets were significantly lower, while aspartate aminotransferase (AST), creatinine, lactate dehydrogenase (LDH), troponin, NT-proBNP, C-reactive protein (CRP), interleukin-6 (IL-6), ferritin, prothrombin time (PT), APTT and D-Dimer were significantly higher in dead cases (all $P<0.05)$. (Supplementary table 1 )

\section{Treatment and outcomes}

$43.6 \%$ of the patients received nasal cannula, $2.1 \%$ oxygen mask, $49.3 \%$ non-invasive mechanical ventilation (NMV)/high-flow nasal cannula (HFNC) and 8.6\% invasive mechanical ventilation (IMV)/extracorporeal membrane oxygenation (ECMO). Compound Methoxamine capsule were used in more patients with influenza IgM positive than the other group $(23.3 \%$ vs $9.0 \%, P=0.0222)$. (Table 2$)$ Higher levels of respiratory support were more seen in dead patients, especially those with influenza IgM positive. (Supplementary table 1 and Supplementary table 2)

According to the score of CURB-65, more COVID-19 patients with influenza IgM positive group were in low to moderate risk level $(P=$ 0.0397). No differences were observed in the duration of viral shedding, the length of hospital stay and time from illness onset to discharge between groups. $9.3 \%$ of the patients died in hospital and the rate of death was significantly lower in patients with IgM positive than those with IgM negative (4.1\% vs $14.9 \%, P=0.0276)$. (Table 2 )

Table 2. Treatment and prognosis of COVID-19 Patients with and Without Influenza IgM positive.

\begin{tabular}{|c|c|c|c|c|}
\hline Study Population & With influenza IgM positive $(n=73)$ & Without influenza IgM positive $(n=67)$ & $\begin{array}{c}\text { Total } \\
(\mathrm{n}=140)\end{array}$ & $P$ value \\
\hline \multicolumn{5}{|l|}{ Treatment in hospital } \\
\hline \multicolumn{5}{|l|}{ Oxygen Therapy } \\
\hline Nasal Cannula & $32(43.8)$ & $29(43.3)$ & $61(43.6)$ & 0.9475 \\
\hline Oxygen Mask & $1(1.4)$ & $2(3.0)$ & $3(2.1)$ & 0.5069 \\
\hline NMV/High-flow nasal cannula & $35(47.9)$ & $34(50.7)$ & $69(49.3)$ & 0.7405 \\
\hline IMV/ECMO & $7(9.6)$ & $5(7.5)$ & $12(8.6)$ & 0.6535 \\
\hline \multicolumn{5}{|l|}{ Drugs } \\
\hline Oseltamivir & $33(45.2)$ & $23(34.3)$ & $56(40.0)$ & 0.1894 \\
\hline Arbidol & $53(72.6)$ & $47(70.1)$ & $100(71.4)$ & 0.7482 \\
\hline Compound Methoxamine capsule & $17(23.3)$ & $6(9.0)$ & $23(16.4)$ & 0.0222 \\
\hline \multicolumn{5}{|l|}{ Clinical outcomes } \\
\hline CURB-65 & & & & 0.0397 \\
\hline Low risk & $65(89.0)$ & $50(74.6)$ & $115(82.1)$ & \\
\hline Medium risk & $6(8.2)$ & 8 (11.9) & $14(10.0)$ & \\
\hline High risk & $2(2.7)$ & $9(13.4)$ & $11(7.9)$ & \\
\hline Duration of viral shedding, days & $26.0(20.0,32.0)$ & $25.0(21.0,32.0)$ & $25.5(20.5,32.0)$ & 0.9694 \\
\hline Hospital length of stay, days & $13.0(10.0,18.0)$ & $14.0(10.0,17.0)$ & $13.0(10.0,18.0)$ & 0.9084 \\
\hline Time from illness onset to discharge, days & $27.0(22.0,35.0)$ & $27.0(21.0,33.0)$ & $27.0(22.0,33.5)$ & 0.6208 \\
\hline Death ,No (\%) & & & & 0.0276 \\
\hline Discharge & $70(95.9)$ & $57(85.1)$ & $127(90.7)$ & \\
\hline Death & $3(4.1)$ & $10(14.9)$ & $13(9.3)$ & \\
\hline
\end{tabular}

Severe COVID-19 Patients with influenza virus IgM positive have a higher cumulative survivor rate than that of patients with influenza virus IgM negative (Log-rank $P=0.0308$ ). Considering age is a potential confounding variable, difference in age was adjusted between different influenza virus IgM status groups, the HR was 0.29 (95\% Cl, 0.081-1.100). Similarly, difference in gender was adjusted as above, the HR was $0.262(95 \% \mathrm{Cl}, 0.072-0.952)$ in the COX regression model. (Figure 2)

\section{Discussion}

In this retrospective cohort study, we described the clinical features and outcomes of hospitalized COVID-19 patients with different influenza virus IgM status. We found that influenza virus IgM positive may be associated with decreasing in-hospital death. Fatigue and myalgia were less presented in COVID-19 patients with influenza virus IgM positive. It is the first time for influenza virus IgM to be a prognostic factor of COVID-19.

Previous studies reported cases with co-infection of SARS-CoV-2 and influenza showed the implications of co-infection during the pandemic area[17-20]. It was necessary to assess the effect of the SARS-CoV-2 and influenza co-infection in clinical outcomes. Previous studies 
demonstrated that influenza virus-specific IgM antibody responses follow primary influenza virus infection in adults[11, 21]. Serological confirmation of a clinical diagnosis is by demonstration of greater rise in functional strain specific antibody titer. Specific neutralizing antibody can be detected from about 10 to 14 days post infection, reaches a plateau at around 28 days and decreased to normal level around a month and a half. This test uses nucleocapsid antigens that are type-specific and can distinguish $A$ from $B$ and $C$ infections. Due to the huge task of rapid tests for SARS-CoV-2 and the absence of widely available testing methods, thousands of patients were diagnosed of COVID-19 without identification of co-infection pathogens at the initial period. During the epidemic of seasonal influenza and other respiratory illness, our concern is on the possibility of the co-infection of virus. Therefore, influenza virus IgM antibody may help us review these cases. The outbreak of COVID-19 may occur during influenza season, which brings difficulty in prevention, diagnosis and treatment. Increasing number of literatures has been demonstrating that influenza virus infection may trigger non-neutralizing antibodies responses which also binds to pathogens as diverse as HIV-1, herpes simplex virus and Ebola[22-28]. Some other researches showed that influenza vaccination could reduce cardiovascular morbidity and mortality in patients with COVID-19[29] Therefore, some potential mechanisms including active immunity or passive immunity may involve in the virus immunity for exhibition its protective effects. In this study, influenza virus IgM positive showed as a protective effector in severe COVID-19 patients associated with better prognosis and higher cumulative survivor rate. Considering the potential confounding variables, age and gender were adjusted between different influenza virus IgM status groups, respectively. After that, the potential protective effects influenza virus IgM positive in severe COVID-19 patients were observed If patients are suspected ILI, especially suffering from virus infection, a prompt test, like a one-time diagnostic panel for the respiratory virus nucleic acid, antigen or serological detection of virus specific $\operatorname{lgM} / \mathrm{lgG}$, should be the first step with an expanded detectable rang towards confirming diagnosis, which help in making early and effective prevention and treatment strategy.

The strengths of this study include adults hospitalized with diagnosis of COVID-19, the retrospective cohort design, standardized patient screening in the participating, and centralized confirmation of respiratory viruses and other laboratory indices. Our study has several limitations. Firstly, a large number of patients were continually being admitted to hospital, but the sample size of our study is still limited. Secondly, our study was conducted in a local hospital in Wuhan, which may result in biases. Especially consideration of influenza season, it may become epidemic of different type in different regions. Thirdly, this cohort study did not last for a long time. Missing information of death status at discharge and initial influenza virus IgM status may influence the demographics and available clinical characteristics between included and excluded patients. Thus, the results may partly help us recognize co-infection of influenza and SARS-CoV-2. Further studies focused on the co-infectious pathogens, the treatment and prevention will be needed.

\section{Conclusions}

Influenza virus IgM positive may be associated with decreasing in-hospital death. The co-infection of SARS-CoV-2 and influenza virus may occur by causing a crisis and we need to improve our understanding for confronting it in the future.

\section{List Of Abbreviations}

APTT: activated partial thromboplastin time; CDC: centers for disease control and prevention; COVID-19: coronavirus disease 2019; ECMO: extracorporeal membrane oxygenation; eGFR: estimated glomerular filtration rate; ELISA: enzyme-linked immunosorbent assay; FiO2: fraction of inspired oxygen; HA: hemagglutinin; HFNC: high-flow nasal cannula; ILI: influenza like illness; IQR: interquartile range; LDH: Iactate dehydrogenase; MV: mechanical ventilation; NMV: noninvasive methods of mechanical ventilation; NT-proBNP: N-terminal pro brain natriuretic peptide; PaO2: partial pressure of oxygen; PT: prothrombin time; RT-PCR: reverse-transcriptase-polymerase chain-reaction; SARSCoV: severe acute respiratory syndrome- coronavirus; SARS-CoV-2: severe acute respiratory syndrome- coronavirus -2; WHO: World Health Organization; ALT, alanine transaminase; AST, aspartate aminotransferase; CRP, C-reactive protein; IL-6, interleukin-6; FIB, fibrinogen; NMV, non-invasive mechanical ventilation; IMV, invasive mechanical ventilation.

\section{Declarations}

\section{Ethics approval and consent to participate}

The study was approved by Ethics Committee of Beijing Hospital (2020BJYYEC-046-01).

\section{Consent to publish}

Not applicable.

Availability of data and materials 
All the data from electronic medical records in Tongji Hospital were reviewed by experienced physicians separately and checked by 2 physicians independently.

\section{Competing interests}

The authors declare that they have no competing interests.

\section{Funding}

This project was supported by project grant 81870013 from the National Natural Science Foundation of China; and grant 7202178 from the Natural Science Foundation of Beijing.

\section{Authors' contributions}

Yanming Li and Xunliang Tong contributed to the conception and design of the study and interpretation of the results and drafted the manuscript. Xunliang Tong, Xiaomao Xu, Guoyue Lv and He Wang contributed to the acquisition of the data and revision of the manuscript for important intellectual content. Anqi Cheng, Yue Zhang, Guohui Fan and Dingyi Wang performed the statistical analysis and revised the manuscript for important intellectual content. All authors read and approved the final manuscript.

\section{Acknowledgments}

The authors thank Academician Chen Wang for his guidance and assistance with this work.

\section{References}

1. Zhou P, Yang XL, Wang XG, Hu B, Zhang L, Zhang W, Si HR, Zhu Y, Li B, Huang CL et al: A pneumonia outbreak associated with a new coronavirus of probable bat origin. Nature 2020, 579(7798):270-273.

2. Kong WH, Li Y, Peng MW, Kong DG, Yang XB, Wang L, Liu MQ: SARS-CoV-2 detection in patients with influenza-like illness. Nature microbiology 2020.

3. Yan R, Zhang Y, Li Y, Xia L, Guo Y, Zhou Q: Structural basis for the recognition of SARS-CoV-2 by full-length human ACE2. Science (New York, NY) 2020, 367(6485):1444-1448.

4. World Health Organization. Coronavirus disease (COVID-19) outbreak https://www.who.int. Date last accessed: April 14, 2020.

5. Wang C, Horby PW, Hayden FG, Gao GF: A novel coronavirus outbreak of global health concern. Lancet (London, England) 2020, 395(10223):470-473.

6. Guan WJ, Ni ZY, Hu Y, Liang WH, Ou CQ, He JX, Liu L, Shan H, Lei CL, Hui DSC et al: Clinical Characteristics of Coronavirus Disease 2019 in China. The New England journal of medicine 2020.

7. Bedford T, Riley S, Barr IG, Broor S, Chadha M, Cox NJ, Daniels RS, Gunasekaran CP, Hurt AC, Kelso A et al: Global circulation patterns of seasonal influenza viruses vary with antigenic drift. Nature 2015, 523(7559):217-220.

8. Yao Y, Zhipeng Z, Wenqi S, Runqing L, Dong Z, Kun Q, Xiuying Z: Unreliable usage of a single influenza virus IgM antibody assay in influenza-like illness: A retrospective study of the 2016-2018 flu epidemic. PloS one 2019, 14(4):e0215514.

9. (CNIC) CNIC. China flu Weekly Report 2020. http://www.chinaivdc.cn/cnic/zyzx/lgzb/202002/t20200209_212403.htm.

10. Wu X, Cai Y, Huang X, Yu X, Zhao L, Wang F, Li Q, Gu S, Xu T, Li Y et al: Co-infection with SARS-CoV-2 and Influenza A Virus in Patient with Pneumonia, China. Emerging infectious diseases 2020, 26(6).

11. Li ZN, Lin SC, Carney PJ, Li J, Liu F, Lu X, Liu M, Stevens J, Levine M, Katz JM et al: IgM, IgG, and IgA antibody responses to influenza $\mathrm{A}(\mathrm{H} 1 \mathrm{~N} 1)$ pdm09 hemagglutinin in infected persons during the first wave of the $\mathbf{2 0 0 9}$ pandemic in the United States. Clinical and vaccine immunology : CVI2014, 21(8):1054-1060.

12. Liang WH, Guan WJ, Li CC, Li YM, Liang HR, Zhao Y, Liu XQ, Sang L, Chen RC, Tang CL et al: Clinical characteristics and outcomes of hospitalised patients with COVID-19 treated in Hubei (epicenter) and outside Hubei (non-epicenter): A Nationwide Analysis of China. The European respiratory journal 2020.

13. National Health Commission of the People's Republic of China. Diagnosis and treatment of new coronavirus pneumonia (trial version 7). Accessed March 13, 2020. Available from:

http://www.nhc.gov.cn/yzygj/s7653p/202003/46c9294a7dfe4cef80dc7f5912eb1989/files/ce3e6945832a438eaae415350a8ce964.pdf

14. Cao B, Wang Y, Wen D, Liu W, Wang J, Fan G, Ruan L, Song B, Cai Y, Wei M et al: A Trial of Lopinavir-Ritonavir in Adults Hospitalized with Severe Covid-19. The New England journal of medicine 2020.

Page $7 / 10$ 
15. Oladipo EK, Awoyelu EH, Oloke JK: Assessment of Baseline Antibodies to Pandemic Influenza A/H1N1/2009 Virus in Ogbomoso, Oyo State, Nigeria. Pathogens and global health 2018, 112(4):227-231.

16. Qiu C, Tian D, Wan Y, Zhang W, Qiu C, Zhu Z, Ye R, Song Z, Zhou M, Yuan S et al: Early adaptive humoral immune responses and virus clearance in humans recently infected with pandemic 2009 H1N1 influenza virus. PloS one 2011, 6(8):e22603.

17. Wu X, Cai Y, Huang X, Yu X, Zhao L, Wang F, Li Q, Gu S, Xu T, Li Y et al: Co-infection with SARS-CoV-2 and Influenza A Virus in Patient with Pneumonia, China. Emerging infectious diseases 2020, 26(6):1324-1326.

18. Wu D, Lu J, Ma X, Liu Q, Wang D, Gu Y, Li Y, He W: Coinfection of Influenza Virus and Severe Acute Respiratory Syndrome Coronavirus 2 (SARS-COV-2). The Pediatric infectious disease journal 2020, 39(6):e79.

19. Wehl G, Laible M, Rauchenzauner M: Co-infection of SARS CoV-2 and influenza A in a Pediatric Patient in Germany. Klinische Padiatrie 2020, 232(4):217-218.

20. Kondo Y, Miyazaki S, Yamashita R, Ikeda T: Coinfection with SARS-CoV-2 and influenza A virus. BMJ case reports 2020, 13(7).

21. Burlington DB, Clements ML, Meiklejohn G, Phelan M, Murphy BR: Hemagglutinin-specific antibody responses in immunoglobulin G, A, and $\mathrm{M}$ isotypes as measured by enzyme-linked immunosorbent assay after primary or secondary infection of humans with influenza $A$ virus. Infection and immunity 1983, 41(2):540-545.

22. Forthal DN, Landucci G, Daar ES: Antibody from patients with acute human immunodeficiency virus (HIV) infection inhibits primary strains of HIV type 1 in the presence of natural-killer effector cells. J Virol 2001, 75(15):6953-6961.

23. Haynes BF, Gilbert PB, McElrath MJ, Zolla-Pazner S, Tomaras GD, Alam SM, Evans DT, Montefiori DC, Karnasuta C, Sutthent R et al: Immune-correlates analysis of an HIV-1 vaccine efficacy trial. The New England journal of medicine 2012, 366(14):1275-1286.

24. Kohl S, Loo LS, Pickering LK: Protection of neonatal mice against herpes simplex viral infection by human antibody and leukocytes from adult, but not neonatal humans. Journal of immunology (Baltimore, Md : 1950) 1981, 127(4):1273-1275.

25. Kohl S, Loo LS: Protection of neonatal mice against herpes simplex virus infection: probable in vivo antibody-dependent cellular cytotoxicity. Journal of immunology (Baltimore, Md : 1950) 1982, 129(1):370-376.

26. Wang K, Tomaras GD, Jegaskanda S, Moody MA, Liao H-X, Goodman KN, Berman PW, Rerks-Ngarm S, Pitisuttithum P, Nitayapan S et al: Monoclonal Antibodies, Derived from Humans Vaccinated with the RV144 HIV Vaccine Containing the HVEM Binding Domain of Herpes Simplex Virus (HSV) Glycoprotein D, Neutralize HSV Infection, Mediate Antibody-Dependent Cellular Cytotoxicity, and Protect Mice from Ocular Challenge with HSV-1. J Virol 2017, 91(19).

27. Gunn BM, Yu W-H, Karim MM, Brannan JM, Herbert AS, Wec AZ, Halfmann PJ, Fusco ML, Schendel SL, Gangavarapu K et al: A Role for Fc Function in Therapeutic Monoclonal Antibody-Mediated Protection against Ebola Virus. Cell Host Microbe 2018, 24(2).

28. Saphire EO, Schendel SL, Fusco ML, Gangavarapu K, Gunn BM, Wec AZ, Halfmann PJ, Brannan JM, Herbert AS, Qiu X et al: Systematic Analysis of Monoclonal Antibodies against Ebola Virus GP Defines Features that Contribute to Protection. Cel/ 2018, 174(4).

29. Behrouzi B, Araujo Campoverde MV, Liang K, Talbot HK, Bogoch II, McGeer A, Fröbert O, Loeb M, Vardeny O, Solomon SD et al: Influenza Vaccination to Reduce Cardiovascular Morbidity and Mortality in Patients With COVID-19: JACC State-of-the-Art Review. J Am Coll Cardiol 2020, 76(15):1777-1794.

\section{Figures}




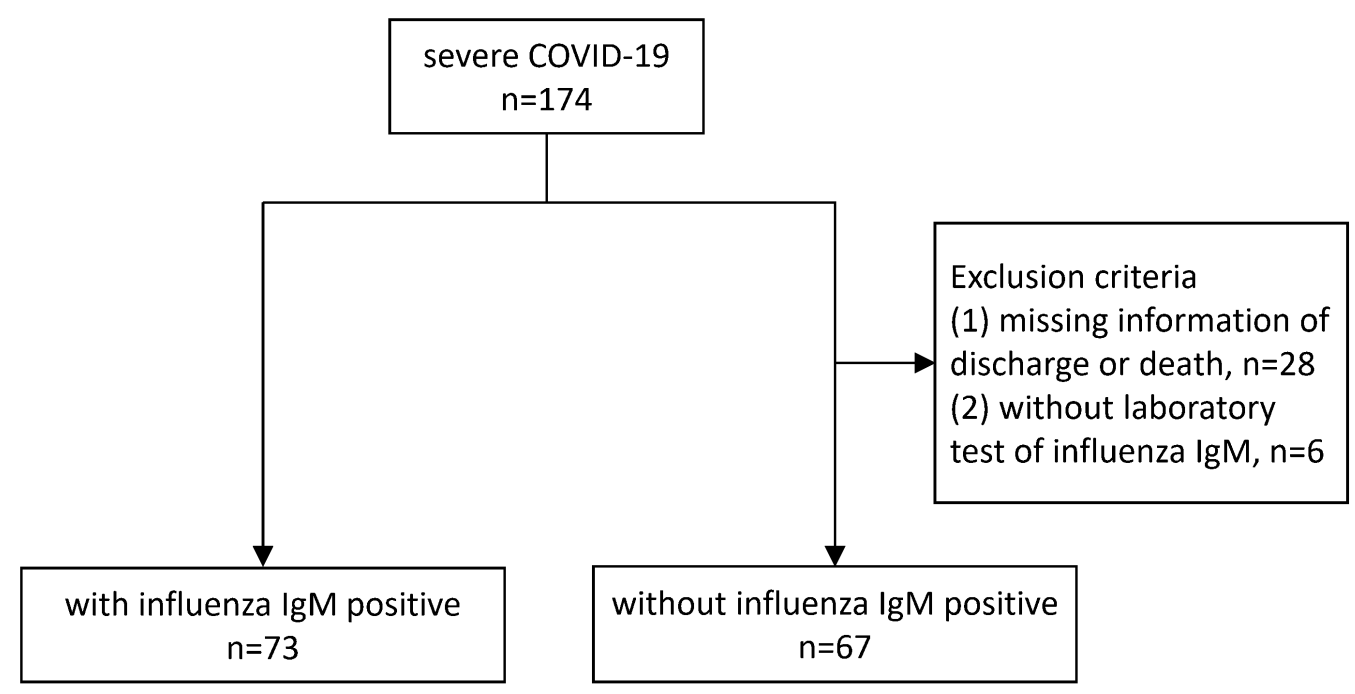

Figure 1

Flow chart 


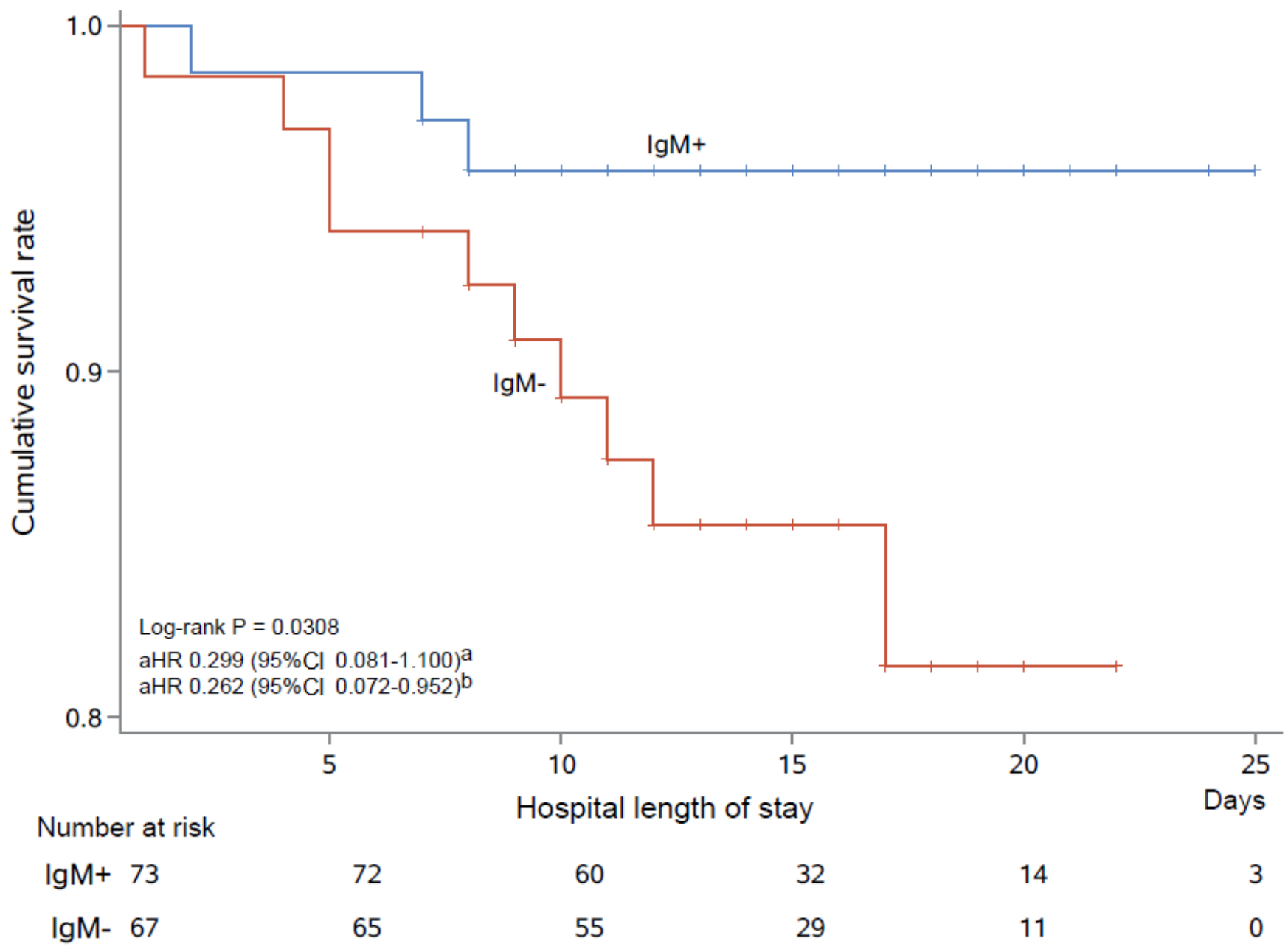

Note. HR and $95 \% \mathrm{Cl}$ were estimated by $\mathrm{COX}$ regression model. a, HR adjusted for age; $\mathrm{b}, \mathrm{HR}$ adjusted for gender. $\mathrm{HR}$, hazard ratio; $95 \% \mathrm{Cl}, 95 \%$ confidence interval.

Figure 2

Cox regression model

\section{Supplementary Files}

This is a list of supplementary files associated with this preprint. Click to download.

- SupplementaryTable1.docx

- SupplementaryTable2.docx 